\title{
Evaluation of the Secondary Metabolites of the Waste Pomegranate Rind and its Cytotoxicity against Oral Cancer (KB 3-1)
}

\author{
Jesse Joel T.* (D), Jagadish Kumar Suluvoy and Jency Varghese \\ Department of Biotechnology, Karunya Institute of Technology and Sciences, Coimbatore - 641 114, \\ Tamil Nadu, India.
}

\begin{abstract}
Cancer is life threatening disease which decrease the quality of the human life and the available medicine to treat the cancer has adverse side effects. The current investigation is to uncover natural products to treat cancer without any side effects. Punica granatum L. (Pomegranate) belongs to the family fruit-bearing deciduous small plants with unique flavour, taste, nutritionally rich and popular in health promoting characteristics. P. granatum $L$ peels were collected and extracted for phytochemicals analysis using solvent ethanol and the preliminary analysis revealed the presence of phytochemicals. The analytical GC-MS was carried out to confirm the phytochemicals with pharmacologically and biologically active compounds. The anticancer activity of the extract was carried out against oral cancer cell line (KB 3-1) and this peel extract exhibited promising anticancer property. The MTT assay showed 94.53\% inhibition on the oral cancer cell line and clonogenic assay showed decrease in the colonies after treating with the peel extract. These showed positive and encouraging results with efficient anticancer properties and further studies can help identify novel compounds with pharmacological properties for effective cancer treatment.

Keywords: Punica granatum L, phytochemicals, GC-MS, MTT, clonogenic assay, pharmacological.
\end{abstract}

*Correspondence: jessejoel@gmail.com; +91-9487733707

(Received: 03 June 2019; accepted: 27 July 2019)

Citation: Jesse Joel T., Jagadish Kumar Suluvoy and Jency Varghese, Evaluation of the Secondary Metabolites of the Waste Pomegranate Rind and its Cytotoxicity against Oral Cancer (KB 3-1), J Pure Appl Microbiol., 2019; 13(3): 1667-1672. https://doi. org/10.22207/JPAM.13.3.40

C The Author(s) 2019. Open Access. This article is distributed under the terms of the Creative Commons Attribution 4.0 International License which permits unrestricted use, sharing, distribution, and reproduction in any medium, provided you give appropriate credit to the original author(s) and the source, provide a link to the Creative Commons license, and indicate if changes were made. 


\section{INTRODUCTION}

Cancer is the group of abnormal cells which divide unusually by overcoming the normal rules of the cell growth and escape the mechanism of apoptosis. Cancer cells (tumors) can be carried through blood vessels to lymph nodes and cause secondary tumors and effect the other place in the body which is called as metastasis ${ }^{1}$. Due to its unpredicted nature and more than hundred different varieties of cancers with different mechanism in each type of cancer, it is difficult to identify the medication for the cancer. The current available medication for the cancer is surgery, chemotherapy and radiation, which are having different side effects like fever, nausea, xerostomia hair loss, anxiety and weakness in the body ${ }^{2}$. People began using complimentary and alternate medicine to treat cancer, in which 58 therapies were recognized as prophylactic methods for the treatment of oncogenic ailments with no adverse effects and in this herbal and plant based medicine is the best to treat cancer ${ }^{3,4}$. Fruits play pivotal role in the human nutrition by providing supplements (vitamins) and dietary roughage and raw materials. Transparent scientific proof indicate that the regular consumption of fruits can prevent cervical, stomach, pancreatic, bladder cancers, high diet of fruit intake will prevent $20 \%$ of cancers ${ }^{5,6}$.

P. granatum L. have antioxidant ${ }^{7}$, anticancer $^{8}(2006)$ anti-proliferative ${ }^{9}$ and the complete $P$. granatum L. content (peel, seed, leaf and flower) have the free radical scavenging activity. P. granatum $L$. extract exhibited strong antibacterial resistance and high antioxidant activity and enhanced liver and kidney functions ${ }^{10}$. The $P$. granatum L. having anti-llergic condition against the release of $b$-hexosaminidase from antigen-stimulated rat basophilic leukemia (RBL-2H3) cells and anti-inflammatory effect on human keratinocyte cells ${ }^{11}$. $P$. granatum $L$. has well-known for its ethnomedical properties with beneficial biological features, the biomolecules available in this fruit is used for as substitutes for synthetic food additives, as nutraceuticals and chemo-preventive agents ${ }^{12}$. P. granatum $L$. showed in vivo anti-inflammatory activity in mice, it inhibited the neutrophil MPO activity and attenuates LPS-induced lung inflammation in mice ${ }^{13}$. This P.granatum L. inhibited type 2 diabetes ${ }^{14}$ and it can fight against atherosclerosis and cardiovascular diseases ${ }^{15}$. Other than this biological activity $P$. granatum $L$. can be utilized as biosorbent to remove nickel from water and the maximum adsorption potential of peel adsorbent for nickel removal was Ca. $52 \mathrm{mg} \mathrm{g}^{-1}$.

Based on the established report on the $P$. granatum $L$. benefits and ayurvedic therapies utilization of this fruit has increased. The current aim of the study is to extract the phytochemicals from the $P$. granatum $L$. peels for the phytochemical analysis, GC-MS and anticancer properties against oral cancer (Human) cell line. The available phytochemicals through GC-MS can be done further research to give biologically important and useful compounds for the human welfare and finding the advantageous compounds for the treatment of cancer.

\section{MATERIALS AND METHODS \\ Collection of Plant material}

The $P$. granatum L. (Pomegranate) fruit peels were collected from Coimbatore district Tamil Nadu region India. The plant was authenticated by the Botanical Survey of India, Coimbatore, Tamil Nadu, and the authentication number is (BSI/ SRC/5/23/2017/Tech.). The $P$. granatum $L$. peels were washed thoroughly under running tap water and shade dried at room temperature.

\section{Cell line}

The KB 3-1 oncogenic cell culture was obtained from the National Cancer Institute (Maharashtra, India). Their concentration of cells was determined using a haemocytometer. The obtained cell line was sub-cultured and kept for further use.

\section{Chemicals}

The chemicals used in this experiments were purchased from Hi-Media (Mumbai, India). All other chemicals used for the experiments were of analytical reagent grade.

\section{Preparation of $P$. granatum $L$. rind extract}

The dried peels of $P$. granatum $L$. was grinded into powder and extracted with ethanol by using continuous hot extraction method. The obtained product was concentrated using vacuum rotary evaporator and the extract was preserved in the freezer $\left(4^{\circ} \mathrm{C}\right)$ for further use.

Phytochemical analysis

Test for Alkaloids

The crude extracts were heated with 
$2 \%$ Hydrochloric acid on a heated liquid bath and chilled, sieved then treated with the Mayer's reagent, presence of yellow precipitation or turbidity confirmed the presence of Alkaloids ${ }^{17}$.

Test for phenols

Crude extract $+2 \%$ solution of $\mathrm{FeCl}_{3}=\mathrm{A}$ blue-green or black coloration ${ }^{18}$.

\section{Test for flavonoids}

A few aliquots of $1 \%$ aluminium solution were suspended into a part of the aqueous plant extract. A yellow coloration specifies that the flavonoids are present ${ }^{19}$.

Test for Tanins

Crude extract + Gelatine solution + sodium chloride $=$ white precipitate $e^{20}$.

\section{Test for Saponins}

formation ${ }^{21}$.

Distilled water + crude extract $=$ Foam

\section{Test for steroids}

$2 \mathrm{ml}$ of chloroform + Conc. $\mathrm{H}_{2} \mathrm{SO}_{4}+$ Crude extract + Acetic $=$ Greenish coloration ${ }^{21}$. GC-MS

The $P$. granatum $L$. peel extract administrated for Gas Chromatography- Mass Spectroscopy (GC-MS) analysis to categorize the phytochemicals present in it. The temperature of the column was set to $80-250^{\circ} \mathrm{C}$ at $8^{\circ} \mathrm{C} / \mathrm{min}$ rate. Helium act as a transporter gas at a flow rate of $1.0 \mathrm{ml} / \mathrm{min}$. The Thermo GC-Trace Ultra VER: 5.0 (Bremen, Germany) and Mass Spectroscopy (MS) MS DSQ II electron ionization mode with ionization energy of $70 \mathrm{eV}$ was employed. $1 \mu \mathrm{l}$ of sample was used for analysis. Using the retention time and mass fragmentation patterns, a comprehensive analysis of the fruit extract components were established. The National Institute of Standards and Technology (NIST) and Wiley 9.0 library helped identify and correlate the various compounds present in the sample.

\section{MTT Assay}

The anti-cancer property of ethanolic $P$. granatum $L$. peel extract was analysed by the MTT assay using KB 3-1 (Human) cancer cell line. Yellow soluble MTT substrate was reduced by the formazan by the living cells. $0.1 \mathrm{ml}$ of $K B$ 3-1 (Human) cancer cell line were $\left(1.5 \times 10^{6}\right.$ cells/well) seeded in ELISA plate and incubated for 24 hours in $\mathrm{Co}_{2}$ incubator at $37^{\circ} \mathrm{C}$, after 24 hours incubation cells were treated with the $P$. granatum $L$. extract at different concentrations of $50 \mu \mathrm{g}, 100 \mu \mathrm{g}, 150 \mu \mathrm{g}$,
$200 \mu \mathrm{g}, 250 \mu \mathrm{g}, 300 \mu \mathrm{g}$ and $350 \mu \mathrm{g}$ was added to the wells, and then plate was kept for incubation for $24 \mathrm{hrs}$. Then, the cell culture was removed and the plate was washed with PBS. $90 \mu$ of fresh media was added to each well and incubated for three hours. Then $10 \mu \mathrm{l}$ of MTT $(5 \mathrm{mg} / \mathrm{ml})$ was added to each well and the plate was kept for 2 hours incubation. $50 \mu$ l of DMSO was added in each well to stop the mechanism and readings were taken at $570 \mathrm{~nm}$ by ELISA plate reader. The percentage of inhibition was calculated by the formulae,

$\%$ Inhibibtion = OD of the Control - OD of the Test / OD of the Control * 100

\section{RESULTS AND DISCUSSION}

The second most dangerous disease in the world is cancer and in accordance with the World Health Organisation (WHO) there are apparently 14 million established oncological cases with a mortality rate of 8.2 million in 2012. Major drawback in curing the disease is lack of proper medicine and the available medicine is having the adverse side effects. Humans started getting medicine from nature and this nature is embedded with inestimable treasure called plants which are more beneficial to human's life. These plants are used as traditional medicine against different kind of diseases from ancient days. Although several medicine available to cure diseases, it has many side effects which will decrease the quality of the human life ${ }^{23}$. This herbal medicine once again flourishing in world for the human welfare to cure diseases with any side effects and according to WHO survey $(2008) 1 / 8^{\text {th }}$ of ecosphere's population depend on the ecological health and balance for medicines. P. granatum $L$. is known as an ornamental plant and it also produce

Table 1. The presence of different phytochemicals in the P.granatum $L$. peel extract and it's observed that the absence of steroids and saponins and the presence of phenols, Alkaloids, Flavonoids and Tanins

\begin{tabular}{lcc}
\hline NO. & Phytochemicals & Presence \\
\hline 1 & Alkaloids & -ve \\
2 & Phenols & $+\mathrm{ve},+\mathrm{ve}$ \\
3 & Flavonoids & $+\mathrm{ve}$ \\
5 & Tannins & $+\mathrm{ve}$ \\
6 & Saponins & $-\mathrm{ve}$ \\
7 & Steroids & $-\mathrm{ve}$ \\
\hline 69 & & www.microbiologyjournal.org
\end{tabular}


Table 2. Phytochemicals observed with more than $25 \%$ probability by GC-MS analysis

\begin{tabular}{|c|c|c|c|c|}
\hline No. & Compound Name & $\begin{array}{l}\text { Probability } \\
\text { Formula }\end{array}$ & $\begin{array}{l}\text { Molecular } \\
\text { Weight }\end{array}$ & Molecular \\
\hline 1. & 2-Furancarboxaldehyde (CAS) & 38.2 & $\mathrm{C}_{5} \mathrm{H}_{4} \mathrm{O}_{2}$ & 96 \\
\hline 2. & Furfural & 38.20 & $\mathrm{C}_{5} \mathrm{H}_{4} \mathrm{O}_{2}$ & 96 \\
\hline 3. & $\begin{array}{l}\text { 2,3-Dihydro-3,5-dihydroxy-6- } \\
\text { methyl-4H-pyran-4-one }\end{array}$ & 83.27 & $\mathrm{C}_{6} \mathrm{H}_{8} \mathrm{O}_{4}$ & 144 \\
\hline 4. & $\begin{array}{l}\text { 4H-Pyran-4-one, 2,3-dihydro-3, } \\
\text { 5-dihydroxy-6-methyl(flavinoid) }\end{array}$ & 83.27 & $\mathrm{C}_{6} \mathrm{H}_{8} \mathrm{O}_{4}$ & 144 \\
\hline 5. & $\begin{array}{l}\text { 2-Furancarboxaldehyde, 5- } \\
\text { (hydroxymethyl)- (CAS) (saponin) }\end{array}$ & 68.88 & $\mathrm{C}_{6} \mathrm{H}_{6} \mathrm{O}_{3}$ & 126 \\
\hline 6. & 5-Hydroxymethylfurfural & 68.88 & $\mathrm{C}_{6} \mathrm{H}_{6} \mathrm{O}_{3}$ & 126 \\
\hline 7. & 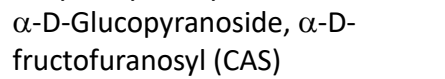 & 39.59 & $\mathrm{C}_{12} \mathrm{H}_{23}^{0} \mathrm{O}_{11}$ & 343 \\
\hline 8. & Hexadecanoic acid, methyl ester & 64.77 & $\mathrm{C}_{17} \mathrm{H}_{34} \mathrm{O}_{2}$ & 270 \\
\hline 9. & di(isityl)di[phosphino]silane & 72.42 & $\mathrm{C}_{30} \mathrm{H}_{50} \mathrm{P}_{2}^{2} \mathrm{Si}$ & 500 \\
\hline 10. & $\begin{array}{l}\text { 1-Propyl-3,6-diazahomoa- } \\
\text { damantan-9-ol }\end{array}$ & 34.06 & $\mathrm{C}_{12} \mathrm{H}_{22} \mathrm{~N}_{2} \mathrm{O}$ & 210 \\
\hline
\end{tabular}

edible fruit with rich source of antioxidants. All the parts of a pomegranate fruit have the free radical scavenging activity (antioxidant property). The study shows that peel has highest antioxidant property from other parts of the fruit ${ }^{24}$ Wang et al., (2011). Antioxidants contents were as follows: seed < leaf < flower < peel ${ }^{25}$ Elfalleh et al., (2012). Moreover, another study proved that the peel of the pomegranate showed maximum antioxidant property among 28 others ${ }^{26}$. Pomegranate peel consists of high number of phytochemicals that are necessary to fight against cancer cells and also this pomegranate peel have antibacterial, anti-allergic activities, anti microbial, tyrosinase inhibition, anti-hyperglycemic, Antihepatoprotective, anti-proliferation, hepato protective, and antihyperlipidemic properties ${ }^{10}$ Ibrahium, (2010).

In the present study by the preliminary phytochemicals analysis $P$. granatum $L$. peels were collected, dried, powdered and the phytochemicals were extracted by soxhelet extraction ${ }^{27}$ process using ethanol as a solvent and it was found out that it is rich source of Phenols, flavonoids, Alkaloids and Tannins were present. This presence of phytochemicals were further tested by the GC-MS and it showed the presence of biological active compounds present in the $P$. granatum $L$. peel extract. The $P$. granatum $L$. showed anticancer properties against human oral cancer cell line (KB3-1). The extracts was used for testing anticancer properties by MTT Assay ${ }^{28}$. A positive result was obtained and the percentage of inhibition was found and we concluded that as the concentration of extract increases the cell viability decreasesi.e $350 \mu \mathrm{g} / \mathrm{ml}$ it showed 80.88 $\%$ of inhibition. Therefore the pomegranate peel extract showed an encouraging and positive result against KB3-1, which further can used for the analysis of compound against KB3-1 oral cancer cell line.

Table 3. Inhibition of KB 3-1 (Human) oral cancer cell line by the increase in the P.granatum $L$. peel extract concentration

\begin{tabular}{lcc}
\hline No. & $\begin{array}{c}\text { Concentration } \\
(\mu \mathrm{g} / \mathrm{ml})\end{array}$ & $\begin{array}{c}\text { Inhibition } \\
(\%)\end{array}$ \\
\hline 1. & 50 & 23.36 \\
2. & 100 & 27.25 \\
3. & 150 & 32.09 \\
4. & 200 & 49.55 \\
5. & 250 & 61.94 \\
6. & 300 & 71.85 \\
7. & 350 & 80.88
\end{tabular}




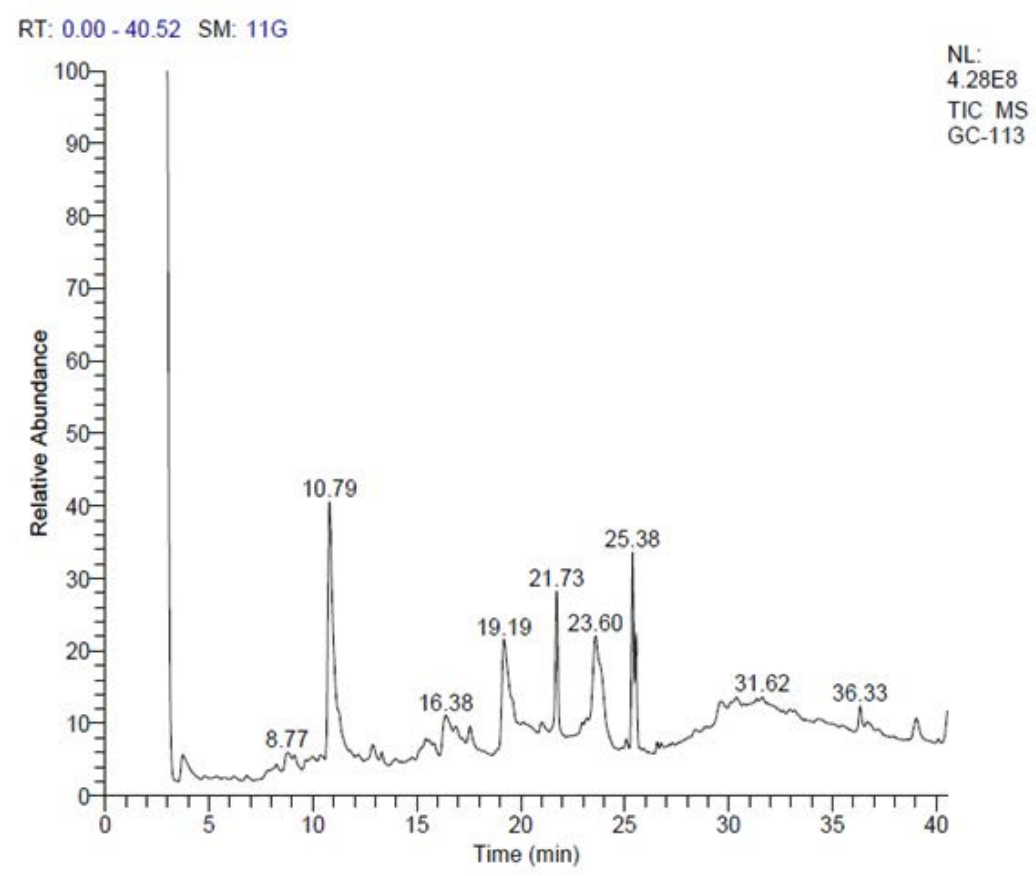

Fig. 1. Chromatogram of the P.granatum L. peel extract showing the peaks at different time intervals and with relative abundance.

\section{ACKNOWLEDGEMENTS}

We would like to thank the Department of Biotechnology for giving us the Research Lab facilities to carry out the work.

\section{CONFLICT OF INTEREST}

The authors declares that there is no conflict of interest.

\section{AUTHORS' CONTRIBUTION}

All authors have made substantial contribution to the work and approved it for publication.

\section{FUNDING}

None.

\section{DATA AVAILABILITY}

All data generated during the study are included in the manuscript.

\section{ETHICS STATEMENT}

The study was undertaken after obtaining approval from the Institutional Research and Ethics Committee.

\section{REFERENCES}

1. Frank, I., Blute, M.L., Cheville, J.C., Lohse, C.M., Weaver, A.L., \& Zincke, H. An outcome prediction model for patients with clear cell renal cell carcinoma treated with radical nephrectomy based on tumor stage, size, grade and necrosis: the SSIGN score. The Journal of Urology, 2002; 168(6): 2395-2400. https://doi. org/10.1016/S0022-5347(05)64153-5

2. Cassileth, Barrie, Jyothirmai Gubili. “Integrative oncology: complementary therapies in cancer care." Supportive care in cancer therapy. Humana Press, 2009; 269-277. https://doi.org/10.1007/9781-59745-291-5_15

3. Mao, J.J., Palmer, C.S., Healy, K.E., Desai, K., \& Amsterdam, J. Complementary and alternative medicine use among cancer survivors: a populationbased study. Journal of Cancer Survivorship, 2011; 5(1): 8-17. https://doi.org/10.1007/s11764-010-0153-7

4. Molassiotis, A., Fernadez-Ortega, P., Pud, D., Ozden, G., Scott, J. A., Panteli, V., Madsen, E. Use of complementary and alternative medicine in cancer patients: a European survey. Annals of Oncology, 2005; 16(4): 655-663. https://doi.org/10.1093/ annonc/mdi110

5. Sun, J., Chu, Y.F., Wu, X., \& Liu, R.H. Antioxidant and antiproliferative activities of common fruits. Journal of Agricultural and Food Chemistry, 2002; 50(25): 74497454. https://doi.org/10.1021/jf0207530

6. Slavin, J.L., \& Lloyd, B. Health benefits of fruits and vegetables. Advances in Nutrition: An International Review Journal, 2012; 3(4): 506-516. https://doi. org/10.3945/an.112.002154 
7. Faria, A., Monteiro, R., Mateus, N., Azevedo, I. \& Calhau, C. Effect of pomegranate (Punica granatum) juice intake on hepatic oxidative stress. European Journal of Nutrition, 2007; 46(5): 271-278. https:// doi.org/10.1007/s00394-007-0661-z

8. Adhami, V.M., \& Mukhtar, H. Polyphenols from green tea and pomegranate for prevention of prostate cancer. Free Radical Research, 2006; 40(10): 1095 1104. https://doi.org/10.1080/10715760600796498

9. Seeram, N.P., Adams, L.S., Henning, S.M., Niu, Y., Zhang, Y., Nair, M.G., \& Heber, D. In vitro antiproliferative, apoptotic and antioxidant activities of punicalagin, ellagic acid and a total pomegranate tannin extract are enhanced in combination with other polyphenols as found in pomegranate juice. The Journal of Nutritional Biochemistry, 2005; 16(6): 360-367. https://doi. org/10.1016/j.jnutbio.2005.01.006

10. Ibrahium, M.I. "Efficiency of pomegranate peel extract as antimicrobial, antioxidant and protective agents." World Journal of Agricultural Sciences, 2010; 6(4): 338-344.

11. Panichayupakaranant, P., S. Tewtrakul, and S. Yuenyongsawad. "Antibacterial, anti-inflammatory and anti-allergic activities of standardised pomegranate rind extract." Food Chemistry, 2010; 123(2): 400-403. https://doi.org/10.1016/j.foodchem.2010.04.054

12. Akhtar, S., Ismail, T., Fraternale, D., Sestili, P. Pomegranate peel and peel extracts: Chemistry and food features. Food Chemistry, 2015; 174: 417-425. https://doi.org/10.1016/j.foodchem.2014.11.035

13. Bachoual, R., Talmoudi, W., Boussetta, T., Braut, F., \& El-Benna, J. An aqueous pomegranate peel extract inhibits neutrophil myeloperoxidase in vitro and attenuates lung inflammation in mice. Food and Chemical Toxicology, 2011; 49(6): 1224-1228. https:// doi.org/10.1016/j.fct.2011.02.024

14. Banihani, S., Swedan, S.,Alguraan, Z. Pomegranate and type 2 diabetes. Nutrition Research, 2013; 33(5): 341 348. https://doi.org/10.1016/j.nutres.2013.03.003

15. Rosenblat, M., Volkova, N., Coleman, R., \& Aviram, $M$. Pomegranate byproduct administration to apolipoprotein e-deficient mice attenuates atherosclerosis development as a result of decreased macrophage oxidative stress and reduced cellular uptake of oxidized low-density lipoprotein. Journal of Agricultural and Food Chemistry, 2006; 54(5): 19281935. https://doi.org/10.1021/jf0528207

16. Bhatnagar, A., Minocha, A.K. \& Sillanpה, M. Adsorptive removal of cobalt from aqueous solution by utilizing lemon peel as biosorbent. Biochemical Engineering Journal, 2010; 48(2): 181-186. https:// doi.org/10.1016/j.bej.2009.10.005

17. Shah, R.K., \& Yadav, R.N.S. Qualitative phytochemical analysis and estimation of total phenols and flavonoids in leaf extract of sarcochlamys pulcherrima Wedd. Global Journal of Bioscience and BioTechnology, 2015; 4: 81-84.
18. Tamilselvi, N. "Analysis of total phenols, total tannins and screening of phytocomponents in Indigofera aspalathoides (Shivanar Vembu) Vahl EX DC." Journal of Chemical and Pharmaceutical Research, 2012; 4(6): 3259-3262.

19. Ayoola, G.A. "Phytochemical screening and antioxidant activities of some selected medicinal plants used for malaria therapy in Southwestern Nigeria." Tropical Journal of Pharmaceutical Research, 2008; 7(3): 10191024. https://doi.org/10.4314/tjpr.v7i3.14686

20. Rai V.M., Pai V.R., Kedilaya H.P., Hegde S. Preliminary phytochemical screening of members of Lamiaceae family: Leucas linifolia, Coleus aromaticus and Pogostemon patchouli. International Journal of Pharmaceutical Sciences Review and Research, 2013; 21: 131-137.

21. Savithramma, N., Rao, M.L., \& Suhrulatha, D. Screening of medicinal plants for secondary metabolites. MiddleEast Journal of Scientific Research, 2011; 8(3): 579-584.

22. Kumar, S.J., Shaji, S. \& Grace, V.B. Anti-lymphoma Activity of Averrhoa bilimbi Fruit Extract in Swiss Albino Mice. Asian Journal of Pharmaceutic, 2016; 10(2): S183.

23. Mukherjee, P.K., Kumar, V. \& Houghton, P.J. Screening of Indian medicinal plants for acetylcholinesterase inhibitory activity. Phytotherapy Research, 2007; 21(12): 1142-1145. https://doi.org/10.1002/ ptr.2224

24. Zhenbin Wang, Zhongli Pan, Haile Ma, Griffiths G. Atungulu. "Extract of Phenolics From Pomegranate Peels", The Open Food Science Journal, 2011; 5: 17-25. https://doi.org/10.2174/1874256401105010017

25. Elfalleh, W., Hannachi, H., Tlili, N., Yahia, Y., Nasri, N., \& Ferchichi, A. Total phenolic contents and antioxidant activities of pomegranate peel, seed, leaf and flower. Journal of Medicinal Plants Research, 2012; 6(32): 4724-4730. https://doi.org/10.5897/ JMPR11.995

26. Yunfeng Li, Changjiang Guo, Jijun Yang, Jingyu Wei, Jing $\mathrm{Xu}$, Shuang Cheng "Evaluation of antioxidant properties of pomegranate peel extract in comparison with pomegranate pulp extract", Food Chemistry, 2006; 96: 254-260. https://doi.org/10.1016/j. foodchem.2005.02.033

27. Kotamballi N. Chidambar Murthy, Guddadarangavvahally K. Jayaprakasha, Ravendra P. Singh, J. Agric, "Studies on Antioxidant Activity of Pomegranate (Punica granatum) Peel Extract Using in Vivo Models" Food Chem., 2002; 50: 4791-4795. https://doi.org/10.1021/jf0255735

28. Alhalili, Z., Figueroa, D., Johnston, M. R., Shapter, J., \& Sanderson, B. Effect of Modification Protocols on the Effectiveness of Gold Nanoparticles as Drug Delivery Vehicles for Killing of Breast Cancer Cells. Australian Journal of Chemistry, 2017; 69(12): 1402-1412. https:// doi.org/10.1071/CH16430 